\title{
Pengaruh Kandungan Senyawa pada Ekstrak Daun Ketapang n-Heksan, Etil Asetat, Metanol dan Campuran Terhadap Nilai Efisiensi Dye Sensitized Solar Cell (DSSC)
}

\author{
Aisyah $^{1^{*}}$, Kurnia Arini Putri ${ }^{1}$, Suriani $^{1}$, Iswadi $^{2}$, Asriani llyas ${ }^{1}$ \\ 'Jurusan Kimia, Fakultas Sains dan Teknologi UIN Alauddin Makassar \\ ${ }^{2}$ Jurusan Fisika, Fakultas Sains dan Teknologi UIN Alauddin Makassar \\ email: aisyah@uin-alauddin.ac.id
}

\begin{abstract}
The needs of electrical energy that increase year by year cause electrical energy crisis. Alternative energy sources which are potential to be developed as a substitute of fossil fuels are organic solar cells or DSSC (Dye Sensitized Solar Cell). The purpose of this study is to determine the value of efficiency resulting from Ketapang leaf extract and to determine the effect of compound content in Ketapang leaf extract toward the value of DSSC efficiency. This study investigate the efficiency value of the DSSC which are senzitized by the N-hexane, ethyl acetate, methanol extract of the Ketapang leaf and the mixture extract. The compounds from each axtract are characterized used UV-Vis and FTIR. The measurement results of the efficiency value from nhexane of Ketapang leaf extract, ethyl acetate, methanol and the mixture were respectively $0.0051 \%, 0.09 \%, 0.12 \%$ and $0.22 \%$. The results of UV-Vis characterization with maximum wavelength were respectively $667 \mathrm{~nm}, 665.9 \mathrm{~nm}, 665.9 \mathrm{~nm}$ and $209 \mathrm{~nm}$. The FTIR identified an auxchrome group such as - $\mathrm{OH}, \mathrm{C}-\mathrm{N},-\mathrm{NH}$, and $\mathrm{C}-\mathrm{O}$ as well as chromophore groups such as $\mathrm{C}=\mathrm{O}$ and $C=C$. These data support that the existence of flavonoid and alcaloid compound in the mixture extract generate significant efficiency value.
\end{abstract}

Keywords:chromophore, DSSC, Ketapang Leaf extract, photosenzitizer, sustainable energy

\section{PENDAHULUAN}

Sumber energi di dunia saat ini masih didominasi oleh energi yang berasal dari bahan bakar fosil seperti minyak bumi, gas alam dan batu bara. Konsumsi kebutuhan energi tersebut lama kelamaan akan mengalami kenaikan. Hal ini, akan mengakibatkan penurunan persediaan bahan bakar fosil di alam dan juga akan berdampak pada krisis energi listrik. Oleh karena itu, para peneliti berusaha mencari sumber energi alternatif yang berkelanjutan sebagai pengganti bahan bakar fosil salah satunya adalah sel surya.

Sel surya dapat mengkonversi energi foton menjadi energi listrik secara langsung dengan arus searah melalui efek fotovoltaik (Subandi \& Handi, 2015). Sel surya telah banyak 
dikembangkan dari segi jenis materinya yaitu sel surya berbahan dasar silikon, sel surya lapis tipis dan Dye Sensitized Solar Cell (DSSC).

Rangkaian alat Dye Sensitized Solar Cell (DSSC) terdiri dari lapisan nano kristal $\mathrm{TiO}_{2}$ berpori sebagai fotonanoda, dye sebagai fotosensitizer, elektrolit sebagai pendonor elektron dan kaca TCO (Transparent Conducting Oxide) sebagai elektroda (Maddu, Zuhri \& Irmansyah, 2007). DSSC mempunyai sepasang elektroda yaitu pada elektroda kerja dilapisi dengan $\mathrm{TiO}_{2}$ yang telah ditetesi oleh zat warna (dye) dan elektroda lawan dilapisi dengan kabon yang berfungsi sebagai katalis (Damayanti, Hardeli \& Sanjaya, 2014). Diantara kedua kaca TCO dialiri larutan elektrolit redoks. Larutan elektrolit redoks yang biasa digunakan yaitu (iodide/triiodide) (Ekasari \& Yudhoyono, 2013).

Dye adalah zat warna alami yang dapat diperoleh dari bahan-bahan alam melalui proses ekstraksi. Beberapa zat warna alami yang terdapat dalam tumbuhan yaitu klorofil, antosianin, flavonoid, tanin dan karatenoid.

Telah banyak zat warna alami yang digunakan dalam pembuatan DSSC seperti ekstrak terminalia chebula dengan nilai efisiensi 0.28\% (Latif \& Abdel, 2013), ekstrak Terminalia bellicia dengan nilai efisiensi 0.026\% (Prasada, et.al. 2016), ekstrak daun jati (Tectona Grandis) menggunakan pelarut n-heksan:metanol dengan fraksi 5:5 diperoleh nilai efisiensi sebesar 0.05\% (Baharuddin, et.al., 2015) dan dari ekstrak metanol:n-heksana cabe merah sebesar 0,034\% (Maming, et.al., 2017). Efisiensi DSSC dengan zat warna sintesis yang digunakan oleh Mathew et.al. (2014) sebesar 13\%. Walaupun zat warna alami lebih memiliki nilai efisiensi yang rendah dibanding dengan zat warna sintesis tetapi biaya produksi zat warna alami lebih murah, zat warna alami banyak terdapat di alam serta ramah lingkungan.

Salah satu zat warna yang dapat dijadikan sebagai Dye Sensitized Solar Cell (DSSC) yaitu zat warna dari daun ketapang. Pohon ketapang banyak terdapat di pinggir jalan atau di taman sebagai pohon peneduh. Daun ketapang masih sangat jarang digunakan untuk kehidupan seharihari sehingga hanya akan terbuang. Kandungan senyawa yang terdapat pada daun ketapang yaitu tanin, saponin, klorofil, flavonoid, alkaloid dan fenol menjadikannya potensial sebagai bahan dasar dye dalam pembuatan DSSC.

\section{METODE PENELITIAN}

Alat

Alat yang akan digunakan pada penelitian ini, yaitu spektrofotometer FTIR Nicolet iS10, spektrofotometer UV-Vis Varian Cary 50 Conc, SEM (Scanning Electron Microscope), multimeter DT-680B, rotary vaccum evaporator, neraca analitik, kaca TCO (Transparant Conductive Oxide), Luxmeter, potensiometer $50 \mathrm{k} \Omega$, hot plate, kabel, alat gelas, batang pengaduk, plat tetes dan spatula. 


\section{Bahan}

Simplisia yang digunakan adalah daun ketapang (Terminalia catappa l.) yang diperoleh dari Kota Makassar, Sulawesi Selatan. Bahan lain yang digunakan pada penelitian ini, yaitu aquadest $\left(\mathrm{H}_{2} \mathrm{O}\right)$, etanol $\left(\mathrm{C}_{2} \mathrm{H}_{5} \mathrm{OH}\right)$, etil asetat $\left(\mathrm{C}_{4} \mathrm{H}_{8} \mathrm{O}_{2}\right)$ (Bratachem), $\mathrm{FeCl}_{3} 5 \%$, iodin $\left(\mathrm{I}_{2}\right)$, kalium iodida (KI), kertas saring biasa, lilin, metanol $\left(\mathrm{CH}_{3} \mathrm{OH}\right)$ (Bratachem), $\mathrm{NaOH} 10 \%$, n-heksan $\left(\mathrm{C}_{6} \mathrm{H}_{14}\right)$ (Bratachem), Pereaksi dragendorf, pereaksi mayer, pereaksi wagner, pereaksi LiebermanBurchard, Titanium dioksida $\left(\mathrm{TiO}_{2}\right)$ katalog 7508.

\section{Prosedur Kerja}

\section{Ekstraksi Serbuk Daun Ketapang}

Daun ketapang dipotong kecil-kecil lalu dikeringkan dalam suhu kamar kemudian sampel diblender hingga daun ketapang menjadi serbuk. Serbuk daun ketapang ditimbang sebanyak 300 gr kemudian diekstraksi. Ekstraksi dimulai dengan pelarut n-heksan, proses perendaman dilakukan selama \pm 24 jam pada suhu kamar selama 3 hari. Dengan cara yang sama, residu dari ekstraksi tadi kemudian diangin-anginkan selama 10 menit lalu dilanjutkan dengan pelarut etil asetat dan tahap akhir residu diekstraksi dengan pelarut metanol. Filtrat yang diperoleh dari masing-masing pelarut kemudian dipekatkan dengan menggunakan rotary vacum evaporator pada suhu $40-60{ }^{\circ} \mathrm{C}$ dan $30 \mathrm{rpm}$ sampai menghasilkan ekstrak kental. Ekstrak kental n-heksan, etil asetat dan metanol ditimbang masing-masing 0.02 gram untuk membuat ekstrak gabungan.

\section{Aplikasi Zat Warna pada DSSC}

\section{Preparasi $\mathrm{TiO}_{2}$}

$\mathrm{TiO}_{2}$ p.a katalog 7508 ditimbang \pm 1 g kemudian dilarutkan dengan menggunakan pelaut etanol $\left(\mathrm{C}_{2} \mathrm{H}_{5} \mathrm{OH}\right)$ sebanyak $5 \mathrm{~mL}$ hingga terbentuk pasta.

\section{Pembuatan larutan elektrolit}

Larutan elektrolit dibuat dari campuran kalium iodida dan Iodin. Kalium iodida ditimbang sebanyak $0.83 \mathrm{~g}$ dan ditambahkan Iodin sebanyak $0.127 \mathrm{~g}$ lalu dilarutkan dalam $10 \mathrm{~mL}$ aquades.

\section{Persiapan elektroda pembanding}

Kaca TCO dibersihkan dengan aquadest dalam ultrasonik kemudian dikeringkan. Setelah itu kaca TCO diukur resistansinya, sisi kaca yang mempunyai resistansi dipanaskan di atas api (lilin) hingga terbentuk warna hitam pada kaca TCO.

\section{Rangkaian perangkat DSSC}

Kaca TCO yang telah dibersihkan lalu diukur resistansinya, kemudian sisi kaca yang mempunyai resistansi ditutup dengan isolasi bening disalah satu sisinya dan dilakukan pelapisan pasta $\mathrm{TiO}_{2}$ p.a kemudian dilakukan proses sintering selama 30 menit. Kaca TCO yang telah dilapisi dengan $\mathrm{TiO}_{2}$ kemudian ditetesi dengan ekstrak daun ketapang dan dibiarkan beberapa menit hingga dye terserap ke dalam $\mathrm{TiO}_{2}$. Selanjutnya dilapisi dengan larutan elektrolit dan 
ditutup dengan elektroda pembanding. Setelah rangkaian DSSC selesai, kemudian disambungkan dengan alat multimeter dan pengukur intensitas cahaya. Lalu disinari dengan sinar matahari dan dicatat arus serta tegangan yang dihasilkan oleh rangkaian DSSC.

\section{Karakterisasi Senyawa pada Ekstrak Daun Ketapang}

Uji dengan skiring fitokimia

1) Uji dengan $\mathrm{FeCl}_{3} 5 \%$

Sampel diencerkan dengan pelarutnya kemudian dipipet ke dalam plat tetes lalu ditetesi dengan $\mathrm{FeCl}_{3} 5 \%$, amati perubahan warna yang terjadi.

2) Uji dengan $\mathrm{NaOH} 10 \%$

Sampel diencerkan dengan pelarutnya lalu dipipet ke dalam plat tetes dan ditetesi dengan $\mathrm{NaOH} 10 \%$. Amati perubahan warna yang terjadi.

3) Pereksi Dragendorf

Sampel diencerkan menggunakan pelarutnya kemudian dipipet kedalam plat tetes dan ditetesi dengan pereaksi Dragendorf. Amati perubahan warna yang terjadi.

4) Pereaksi Mayer

Sampel diencerkan menggunakan pelarutnya kemudian dipipet kedalam plat tetes dan ditetesi dengan pereaksi Mayer. Amati perubahan warna yang terjadi.

5) Pereaksi Wagner

Sampel diencerkan menggunakan pelarutnya kemudian dipipet kedalam plat tetes dan ditetesi dengan pereaksi Wagner. Amati perubahan warna yang terjadi endapan berwarna jingga.

6) Pereaksi Lieberman-Burchard

Sampel diencerkan menggunakan pelarutnya kemudian dipipet ke dalam plat tetes dan ditetesi dengan pereaksi Lieberman-Burchard. Amati perubahan warna yang terjadi.

\section{Uji absorbsi senyawa pada ekstrak kental daun ketapang}

Absorbsi dari senyawa dari ekstrak kental daun ketapang dianalisa dengan menggunakan spektrofotometer UV-Vis Varian Cary 50 Conc. Panjang gelombang cahaya yang digunakan yaitu berkisar antara $400-800 \mathrm{~nm}$.

Uji gugus fungsi pada ekstrak kental daun ketapang

Spektra gugus fungsi dari ekstrak kental daun ketapang dianalisa dengan menggunakan spektrofotometer FTIR Nicolet iS10.

Uji scanning electron microscopy (SEM) 
Kaca TCO dipotong dengan ukuran $0.5 \mathrm{~cm} \times 0.5 \mathrm{~cm}$. Kaca TCO yang telah dibersihkan, diletakkan di atas meja kerja. Salah satu sisinya ditutupi dengan isolasi bening lalu dilakukan proses pelapisan pada $\mathrm{TiO}_{2}$ catalog 7508 kemudan dilakukan sintering selama 30 menit. Kaca TCO yang telah dilapisi kemudian ditetesi dengan ekstrak yang memiliki nilai efesien yang tinggi lalu dibiarkan beberapa menit hingga ekstrak tersebut meresap. Selanjutnya di uji menggunakan SEM.

\section{HASIL DAN PEMBAHASAN}

\section{Hasil Ekstraksi}

Rendemen ekstrak daun ketapang dari pelarut $n$-heksan, etil asetat dan metanol berturutturut dapat dilihat pada Tabel 1 .

Tabel 1. Hasil Ekstraksi Serbuk Daun Ketapang

\begin{tabular}{llcc}
\hline No & Ekstrak Daun Ketapang & $\begin{array}{c}\text { Massa Ekstrak } \\
(\mathbf{g})\end{array}$ & $\begin{array}{c}\text { Rendamen Ekstrak } \\
(\boldsymbol{\%})\end{array}$ \\
\hline 1 & N-Heksan & 10.28 & 3.43 \\
2 & Etil Asetat & 3.38 & 1.13 \\
3 & Metanol & 27.08 & 9.03 \\
\hline
\end{tabular}

\section{Pengukuran Nilai Efesiensi}

Hasil Pengukuran Nilai Efisiensi DSSC dari ekstrak daun ketapang dengan pelarut n-heksan, etil asetat, metanol dan campuran dapat dilihat pada Tabel 2.

Tabel 2. Hasil pengukuran nilai efisiensi DSSC

\begin{tabular}{lllllll}
\hline $\begin{array}{l}\text { Ekstrak } \\
\text { Daun Ketapang }\end{array}$ & $\mathbf{V}$ & $\mathbf{I}$ & Lux & $\begin{array}{l}\mathbf{P}_{\text {in }} \\
\left(\mathbf{m W / \mathbf { c m } ^ { 2 }}\right)\end{array}$ & $\begin{array}{l}\mathbf{P}_{\text {out }} \\
(\mathbf{m W})\end{array}$ & $\mathbf{\eta ( \% )}$ \\
\hline n-heksan & 24 & 4.8 & 12.98667 & 1152.2 & 0.0006675 & 0.005 \\
Etil asetat & 273 & 46.2 & 14.01144 & 12612.6 & 0.0126126 & 0.09 \\
Metanol & 256 & 60.3 & 12.75231 & 15617.7 & 0.0156177 & 0.12 \\
Campuran & 128 & 177.2 & 10.38046 & 22681.6 & 0.0226816 & 0.22 \\
\hline
\end{tabular}

Nilai efisensi yang diperoleh dari ekstrak daun ketapang dari pelarut $\mathrm{n}$-heksan yaitu sebesar $0.005 \%$; etil asetat $0.09 \%$; metanol $0.12 \%$. Dari hasil penelitian sebelumnya (Boyo dan Akinwunmi, 2016) diperoleh nilai efisiensi dari ekstraksi daun ketapang dengan menggunakan pelarut air lebih tinggi dibandingkan dengan menggunakan pelarut etanol yaitu dengan nilai efisiensi sebesar $0.63 \%$. Tingginya nilai efisiensi tersebut dikarenakan sifat kepolaran air lebih tinggi dibandingkan dengan etanol. 
Nilai efisiensi ekstrak gabungan daun ketapang diperoleh sebesar $0.22 \%$. Nilai efisiensi yang diperoleh masih lebih rendah dibandingkan dengan penelitian sebelumnya yang juga menggunakan dye alami diperoleh nilai efisiensi antara 0.3-1.5\%. (Maddu, et.al. 2007)

Meskipun nilai efisiensi yang dihasilkan pada penelitian ini masih rendah, akan tetapi penelitian tentang DSSC masih terus dilakukan untuk mencari nilai efisiensi yang lebih optimal. Melihat kelebihan dari DSSC yaitu ramah lingkungan dan tidak membutuhkan biaya yang mahal.

\section{Karakterisasi Komponen Zat Warna}

Karakterisasi ekstrak daun ketapang dilakukan menggunakan uji skrining fitokimia, spektrofotometer FTIR, UV-Vis. Hasil analisa dari ekstrak daun ketapang menunjukkan adanya senyawa flavonoid dan alkaloid yang juga teridentifiksi pada spektrum UV-Vis.

\section{Uji skrining fitokimia}

Tabel 3. Hasil Uji Skrining Fitokimia

\begin{tabular}{|c|c|c|c|c|c|c|}
\hline \multirow{2}{*}{$\begin{array}{l}\text { Ekstrak } \\
\text { Daun } \\
\text { Ketapang }\end{array}$} & \multicolumn{2}{|c|}{ Uji flavonoid } & \multicolumn{3}{|c|}{ Uji Alkaloid } & \multirow{2}{*}{$\begin{array}{l}\text { Uji } \\
\text { Terpenoid } \\
\text { Lieberman- } \\
\text { burchard } \\
\end{array}$} \\
\hline & $\begin{array}{l}\mathrm{FeCl}_{3} \\
\mathbf{5 \%}\end{array}$ & $\begin{array}{l}\mathrm{NaOH} \\
10 \%\end{array}$ & Wagner & Mayer & Dragondorff & \\
\hline n-heksan & - & - & - & - & + & - \\
\hline Etil asetat & - & + & - & + & + & - \\
\hline Metanol & + & + & - & - & + & - \\
\hline campuran & + & + & - & + & + & - \\
\hline
\end{tabular}

\section{Spektrofotometer $U V$-Vis}

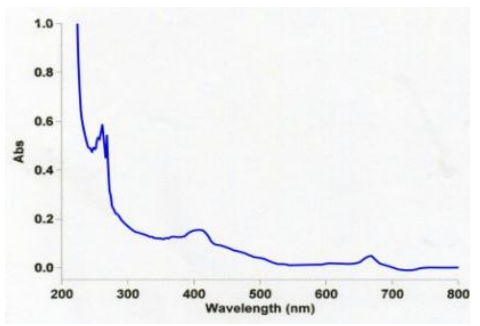

(a)

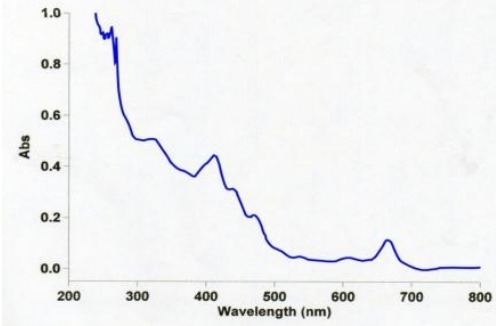

(b) 


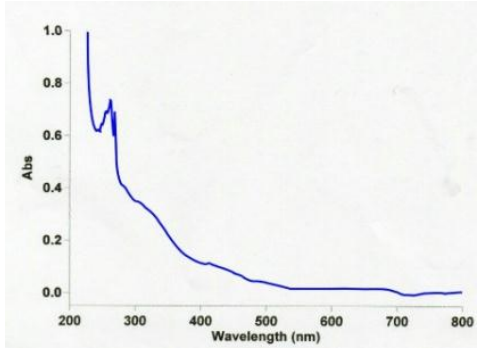

(c)

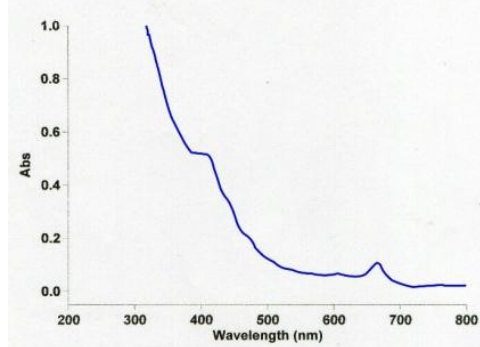

(d)

Gambar 1. Hasil serapan UV-Vis Ekstrak daun ketapang n-heksan (a), etil asetat (b), metanol (c), campuran (d)

Hasil serapan (Gambar 1) yang diperoleh pada ekstrak daun ketapang pelarut metanol, nheksan dan etil asetat berturut-turut yaitu $665.9 \mathrm{~nm}, 667.0 \mathrm{~nm}$ dan $665.9 \mathrm{~nm}$ diidentifikasi senyawa golongan alkaloid yaitu klorofil. Menurut Harbone (1987) pigmen klorofil berdasarkan kurva serapan UV-Vis menunjukkan puncak utama disekitar $400 \mathrm{~nm}$, sejumlah puncak kecil antara 500 dan $600 \mathrm{~nm}$ dan satu puncak utama diatas $625 \mathrm{~nm}$. Sedangkan hasil serapan yang diperoleh pada ekstrak daun ketapang pelarut campuran yaitu $269.0 \mathrm{~nm}$ diidentifikasi sebagai senyawa golongan flavonoid. Menurut Harbone (1987) senyawa flavonoid berada pada panjang gelombang 250-270 $\mathrm{nm}$.

\section{Spektrofotometer FTIR}

Spektrofotometer FTIR digunakan untuk mengetahui gugus fungsi yang terdapat pada ekstrak daun ketapang. Analisis FTIR dilakukan pada panjang gelombang $500-4000 \mathrm{~cm}^{-1}$.

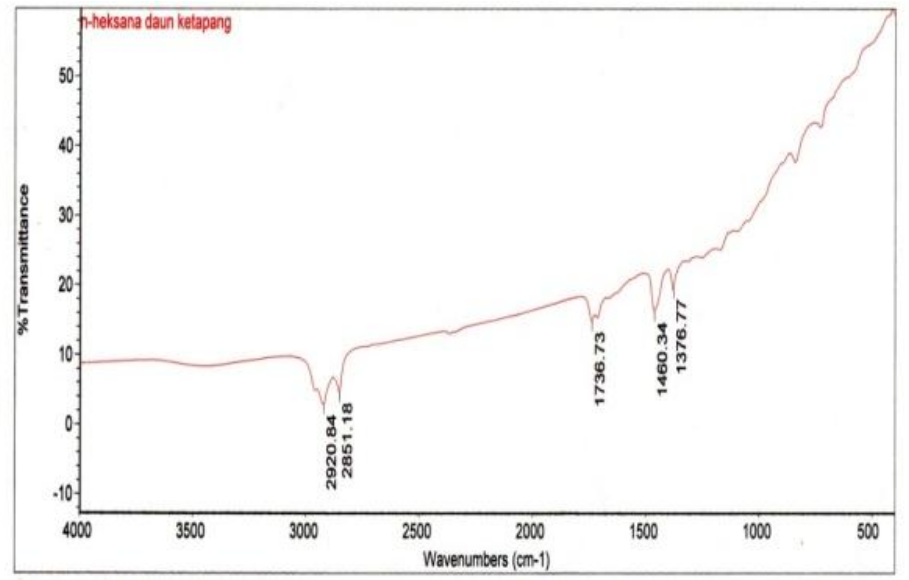

Gambar 2. Hasil Serapan FTIR Ekstrak daun ketapang n-heksan 
Hasil serapan yang diperoleh ekstrak n-heksan yaitu pada bilangan gelombang daerah $1376.77 \mathrm{~cm}^{-1}$ dan $1460.34 \mathrm{~cm}^{-1}$ dengan intensitas sedang diindikasikan adanya aromatik. Gugus $\mathrm{C}=\mathrm{O}$ diindikasikan oleh adanya serapan yang tajam dan lemah pada daerah bilangan gelombang $1736.73 \mathrm{~cm}^{-1}$. Adanya serapan yang sedang dan intensitas sedang dengan panjang gelombang daerah $2851.18 \mathrm{~cm}^{-1}$ dan $2920.84 \mathrm{~cm}^{-1}$ diindikasikan adanya ikatan $\mathrm{C}-\mathrm{H}$ alifatik

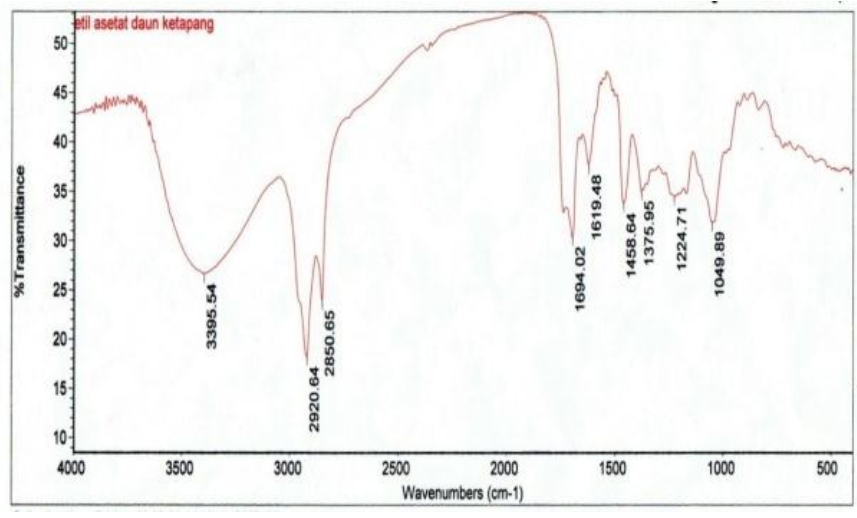

Gambar 3. Hasil Serapan FTIR Ekstrak daun ketapang etil asetat

Hasil serapan yang diperoleh pada ekstrak daun ketapang etil asetat yaitu pola spektrum serapan sedang pada bilangan gelombang $1049.89 \mathrm{~cm}^{-1}$ diindikasikan adanya gugus C-O alkohol. Pada bilangan gelombang daerah $1375.95 \mathrm{~cm}^{-1}$ dengan intensitas lemah diindikasikan adanya gugus amina $(\mathrm{N}-\mathrm{H})$. Diindikasikan adanya gugus $\mathrm{C}=\mathrm{C}$ aromatik dengan intensias lemah pada bilangan gelombang daerah $1458.64 \mathrm{~cm}^{-1}$. Dengan intenstias sedang pada bilangan gelombang daerah $1619.48 \mathrm{~cm}^{-1}$ dan $1694.02 \mathrm{~cm}^{-1}$ diindikasikan adanya gugus $\mathrm{C}=\mathrm{O}$ yang dipengaruhi gugus amina. Adanya intensitas kuat pada bilangan gelombang daerah $2850.65 \mathrm{~cm}^{-1}$ dan $2920.64 \mathrm{~cm}^{-1}$ diindikasikan ikatan $\mathrm{C}-\mathrm{H}$ alifatik. Gugus $-\mathrm{OH}$ diindikasikan oleh adanya serapan kuat pada bilangan gelombang $3395.54 \mathrm{~cm}^{-1}$.

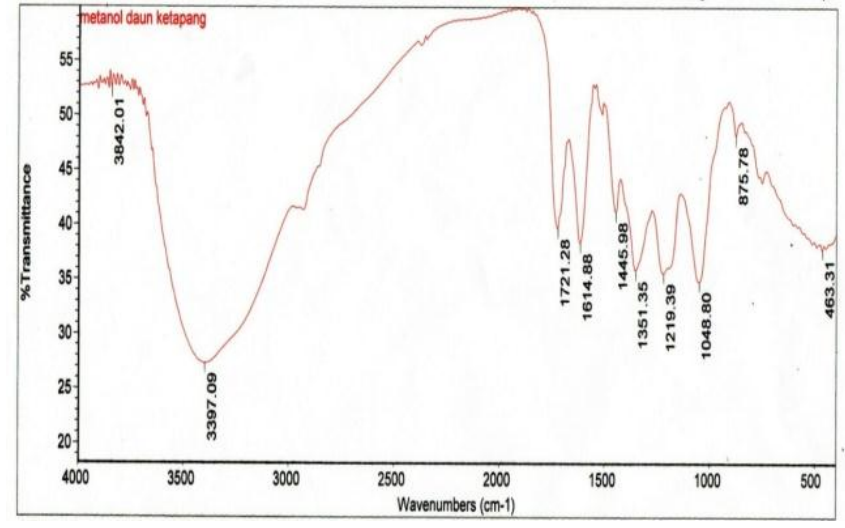

Gambar 4. Hasil Serapan FTIR Ekstrak daun ketapang metanol 
Hasil serapan yang diperoleh pada ekstrak daun ketapang metanol yaitu pada bilangan gelombang daerah $875.78 \mathrm{~cm}^{-1}$ dengan intensitas lemah diindikasikan adanya ikatan C-H alifatik. Diindikasikan adanya gugus - $\mathrm{OH}$ yang bebas pada bilangan panjang gelombang daerah $1048.80 \mathrm{~cm}^{-1}$ dengan intensitas kuat. Adanya intensitas serapan yang kuat pada bilangan panjang gelombang daerah $1219.39 \mathrm{~cm}^{-1}$ diindikasikan a gugus eter dari ikatan aromatik. Pada bilangan panjang gelombang daerah $1351.35 \mathrm{~cm}^{-1}$ dengan intensitas kuat diindikasikan adanya gugus amina $\left(\mathrm{NH}_{2}\right)$. Dengan intensitas sedang pada bilangan panjang gelombang daerah $1445.98 \mathrm{~cm}^{-1}$ diindikasikan adanya ikatan $\mathrm{C}-\mathrm{H}$. Pada bilangan gelombang daerah $1614.88 \mathrm{~cm}^{-1}$ dengan intensitas kuat diindikasikan adanya gugus amina $-\mathrm{NH}$. Diindikasikan adanya ikatan $\mathrm{C}=\mathrm{O}$ yang berasal dari aldehid pada bilangan panjang gelombang daerah $1721.28 \mathrm{~cm}^{-1}$ dengan intensits kuat. Pada bilangan panjang gelomabang daerah $3397.09 \mathrm{~cm}^{-1}$ dengan intensitas kuat diindikasikan adanya gugus $-\mathrm{OH}$.

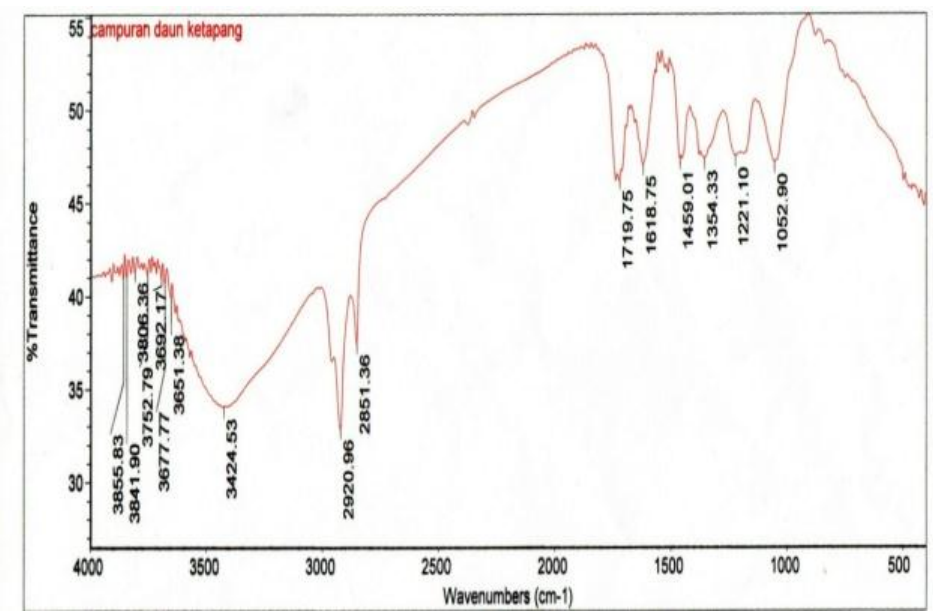

Gambar 5. Hasil Serapan FTIR Ekstrak daun ketapang campuran

Hasil serapan dari ekstrak daun ketapang campuran yang diperoleh yaitu pada bilangan gelombang daerah $1052.90 \mathrm{~cm}^{-1}$ dengan intensitas sedang diindikasikan adanya gugus amina (CN). Pada bilangan gelombang daerah $1221.10 \mathrm{~cm}^{-1}$ dengan intensitas sedang diidnikasikan adanya gugus $\mathrm{C}-\mathrm{O}$. Pada intensitas rendah dengan bilangan gelombang daerah $1354.33 \mathrm{~cm}^{-1}$ diindikasikan adanya ikatan C-H Sp 3 . Pada bilangan gelombang daerah $1460.34 \mathrm{~cm}^{-1}$ dengan intensitas rendah diindikasikan adanya ikatan $\mathrm{C}-\mathrm{H} \mathrm{Sp}_{2}$. Pada bilangan gelombang daerah $1618.75 \mathrm{~cm}^{-1}$ dengan intensitas sedang diindikasikan adanya ikatan $\mathrm{C}=\mathrm{C}$. Diindikasikan adanya gugus $\mathrm{C}=\mathrm{O}$ pada bilangan panjang gelombang daerah $1719.75 \mathrm{~cm}^{-1}$ dengan intensitas sedang. Pada bilangan gelombang daerah $2851.36 \mathrm{~cm}^{-1}$ dan bilangan gelombang daerah $2920.96 \mathrm{~cm}^{-1}$ intensitas kuat dengan intensitas sedang diindikasikan adanya ikatan $\mathrm{C}-\mathrm{H} \mathrm{Sp}{ }_{3}$. Diindikasikan adanya gugus $\mathrm{O}-\mathrm{H}$ pada bilangan panjang gelombang daerah $3424.53 \mathrm{~cm}^{-1}$ dengan intensitas kuat. 
Dari data hasil serapan FTIR dapat dilihat bahwa adanya gugus ausokrom seperti - $\mathrm{OH}, \mathrm{C}-$ $\mathrm{N}$, - $\mathrm{NH}, \mathrm{C}-\mathrm{O}$ dan kromofor seperti $\mathrm{C}=\mathrm{O}, \mathrm{C}=\mathrm{C}$ yang terdapat komponen alkaloid dan flavonoid pada sampel akan mengakibatkan penyerapan panjang gelombang yang maksimal sehingga mengakibatkan semakin tingginya nilai efisiensi DSSC dan hasil pengukuran nilai efisiensi yang tertinggi yaitu pada ekstrak campuran.

\section{Karakterisasi Morfologi Komponen DSSC}

Analisis karakteristik morfologi DSSC dilakukan untuk mengetahui pori pada lapisan $\mathrm{TiO}_{2}$ dan pengikatan dye pada $\mathrm{TiO}_{2}$. Hasil SEM pada $\mathrm{TiO}_{2}$ dan permukaan $\mathrm{TiO}_{2}$ yang telah diberi zat warna dapat dilihat pada Gambar 8.

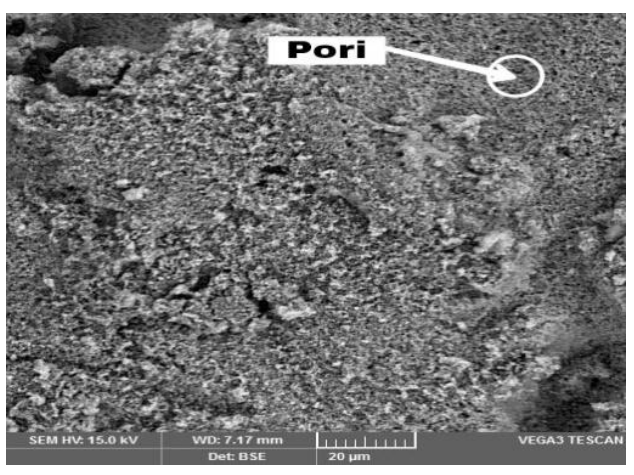

(a)

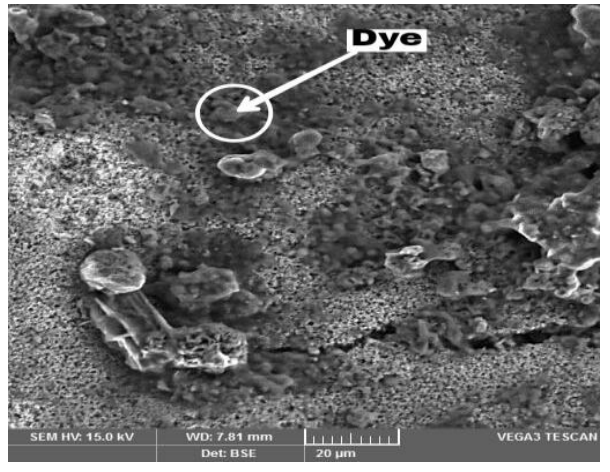

(b)

Gambar 6. Morfoligi $\mathrm{TiO}_{2}$ Perbesaran $20 \mu \mathrm{m}$ (a) Morfologi $\mathrm{TiO}_{2}$ yang Dilapisi dye Perbesaran $20 \mu \mathrm{m}(\mathrm{b})$

Dari Gambar 6 (a) terlihat adanya rongga-rongga atau pori pada permukaan lapisan $\mathrm{TiO}_{2}$. Pori ini berfungsi untuk mengabsorpsi molekul dye. Jumlah pori sangat berpengaruh terhadap penyerapan molekul dye terhadap $\mathrm{TiO}_{2}$ (Lee, dkk: 2007) semakin banyak pori yang terbentuk maka semakin banyak dye yang terabsorsi dalam $\mathrm{TiO}_{2}$ maka semakin meningkat foton yang terserap oleh dye sehingga akan menghasilkan nilai efisiensi yang besar. Gambar 6 (b) terlihat bahwa zat warna tidak tersebar secara merata karena masih ada pori yang belum tertutupi oleh dye. Sebagian dye terserap dengan baik pada $\mathrm{TiO}_{2}$ dan ada juga dye belum terserap pada $\mathrm{TiO}_{2}$, dapat dilihat dari gambar yang dimaksud dye yaitu gambar nampak menggumpal yang menutupi pori-pori dari $\mathrm{TiO}_{2}$.

\section{PENUTUP}

\section{Kesimpulan}

Nilai efisiensi DSSC dengan zat warna dari ekstrak daun ketapang n-heksan, etil asetat, metanol dan campuran berturut-turut yaitu $0.005 \% ; 0.09 \% ; 0.12 \% ; 0.22 \%$. Kandungan senyawa 
alkaloid dan flavonoid yang terdapat pada ekstrak daun ketapang memberikan pengaruh yang signifikan terhadap nilai efisiensi.

\section{DAFTAR PUSTAKA}

Baharuddin, A, Aisyah, Saokani, J., \& Risnah, I.A. (2015). Karakterisasi Zat Warna Daun Jati (Tectona grandis) Fraksi Metanol:N-Heksana Sebagai Photosensitizer pada Dye Sensitized Solar Cell. Chimica et Natura Acta, 3(1), 37- 41.

Damayanti, R., Hardeli \& Sanjaya, H. (2014). Preparasi Dye Sensitized Solar Cell (DSSC) Menggunakan Ekstrak Antosianin Ubi Jalar Ungu (Ipomoea batatas L.). Jurnal Saintek, 6(2), 148-157.

Ekasari, V \& Yudhoyono, G. (2013). Fabrikasi DSSC dengan Ekstrak Jahe Merah (Zingiber offocinale Linn Var. Rubrum) Variasi Larutan $\mathrm{TiO}_{2}$ Nanopartikel Berfase Anatase dengan Teknik Pelapisan Spin Coating, Jurnal Sains dan Seni 2(1), 2337-3520.

Harbone, J.B. 1987. Metode Fitokimia Penuntun Cara Modern Menganalisis Tumbuhan. Bandung: ITB Bandung.

Latif, M. \& S. Abdel, dkk,. (2013). Plant Seeds-Based Dye-Sensitized Solar Cell. Materials Sciences and Applications, 4(4), 516-520.

Lee, S.F., Chang, Y.P., Lee, L.Y. \& Hsu, J.F. (2007). Characterization of Dye Sensitized Solar Cell with ZnO Nanorod, Journal Engineering Technology and Education, 9(5), 545- 552.

Maddu, A., Zuhri, M, \& Irmansyah (2007). Penggunaan ekstrak antosianin kol merah sebagai fotosensitizer pada sel surya $\mathrm{TiO}_{2}$ nanokristal tersensitisasi dye. Jurnal Teknologi ,11(2), 78-84.

Maming, M. S., Aisyah, Suriani \& Iswadi, (2017). Photosenzitizer dari Fraksi Metanol: NHeksan Buah Cabe Merah (Capsicum annum L.). Al-Kimia, 5(1), 31-38.

Mathew, S., Yella, A., Gao, P., Humphry-Baker, R., Basile F. E. Curchod, Ashari-Astani, N., Tavernelli, I., Rothlisberger, U., Nazeeruddin, M.K,... Gra“tzel, M. (2014). DyeSensitized Solar Cells with 13\% Efficiency Achieved Through the Molecular Engineering of Porphyrin Sensitizers. Nature Chemistry, 6(3), 242-247.

Subandi \& Handi, S. (2015). Pembangkit Listrik Energi Matahari Sebagai Penggerak Pompa Air dengan Menggunakan Solar Cell. Jurnal Teknologi Technoscientia ,7(2), 157-163. 